\section{PCR in the investigation of canine American tegumentary leishmaniasis in northwestern Paraná State, Brazil}

\author{
Aplicação do teste de reação em cadeia \\ da polimerase (PCR) no estudo da leishmaniose \\ tegumentar americana em cães, na região \\ noroeste do Paraná, Brasil
}

\author{
Leonardo Garcia Velasquez 1 \\ Norberto Membrive 2 \\ Umberto Membrive ${ }^{\dagger}$ \\ Gesse Rodrigues 2 \\ Nélio Reis 2 \\ Maria Valdrinez Campana Lonardoni ${ }^{3}$ \\ Ueslei Teodoro 3 \\ Ione Parra Barbosa Tessmann 4 \\ Thaís Gomes Verzignassi Silveira ${ }^{3}$
}

\author{
1 Programa de Pós-graduação \\ em Análises Clínicas \\ Universidade Estadual de \\ Maringá, Maringá, Brasil. \\ $216 \underline{a}$ Regional de Saúde \\ de Apucarana, Secretaria \\ de Saúde do Paraná, \\ Arapongas, Brasil. \\ 3 Departamento de Análise \\ Clínicas, Universidade \\ Estadual de Maringá, \\ Maringá, Brasil. \\ 4 Departamento de \\ Bioquímica, Universidade \\ Estadual de Maringá, \\ Maringá, Brasil. \\ $\dagger$ Deceased. \\ Correspondence \\ T. G. V Silveira \\ Programa de Pós-graduação \\ em Análises Clínicas, \\ Universidade Estadual \\ de Maringá. \\ Av. Colombo 5790 \\ Maringá, $P R$ \\ 87020-900, Brasil. \\ tgvsilveira@uem.br
}

\section{Abstract}

American tegumentary leishmaniasis (ATL) was studied in 143 dogs in a rural area in the county of Mariluz, northwestern Paraná State, Brazil, using direct parasite search, indirect immunofluorescence (IIF), and polymerase chain reaction (PCR). Thirty-nine dogs (27.3\%) presented lesions suggestive of the disease, 5 (12.8\%) of which were positive in direct parasite search and PCR (lesion), and of these 5, 4 were also positive by IIF. Of the 34 dogs with negative direct parasite search, 12 (35.3\%) had PCR-positive lesions, and of these, 5 were also IIF-positive. One hundred and four dogs had no lesions, but 17/101 (16.8\%) were IIF-positive. PCR in blood was positive in 10/38 (26.3\%) of the dogs with lesions and in 16/104 (15.4\%) of dogs without lesions. The association between PCR (lesion or blood), direct parasite search, and IIF detected 24/39 (61.5\%) positive results among symptomatic dogs and 31/104 (29.8\%) among asymptomatic animals. PCR was useful for diagnosing ATL, but there was no correlation between lesions, serology, and plasma PCR. Furthermore, detection of parasite DNA in the blood may indicate hematogenous parasite dissemination.

Leishmaniasis; Leishmania (Viannia) braziliensis; Polymerase Chain Reaction; Indirect Fluorescent Antibody Technique; Dogs

\section{Introduction}

American tegumentary leishmaniasis (ATL) is a zoonosis caused by parasites of the Leishmania genus, transmitted by bites from infected Phlebotominae, genus Lutzomyia ${ }^{1}$. Within this genus, Leishmania (Viannia) braziliensis is one of the key causative species of tegumentary leishmaniasis, which can cause all the way from localized skin lesions to severe mucocutaneous mutilations 1 .

Tegumentary leishmaniasis is currently concentrated in South America, the Middle East, and India 2. In Brazil, ATL has been found in all of the States 3,4 due to the intense destruction of native forests and adaptation of vectors to the peri-domiciliary environment 5,6 .

Besides humans, ATL also affects domestic animals like canines and equids. The presence of dogs infected with Leishmania or with positive serology has been reported in endemic areas 7,8,9. In the northwestern region of Paraná State, dogs infected with $L$. (V.) braziliensis 10 and those with positive ATL serology have been detected 3 . Various authors have shown that dogs may play a role in the ATL transmission cycle, acting as a possible secondary reservoir for the parasite 8,9, $11,12,13,14$. However, many questions need still to be answered to elucidate the role of canines in the parasite's transmission cycle $13,14,15$.

ATL diagnosis is performed by direct parasite search in lesions and antibody testing, be- 
sides delayed hypersensitivity reaction (Montenegro skin test) $1,16,17,18$. However, these tests have certain limitations such as: low sensitivity for direct parasite search, mainly in chronic infections 13,18,19,20, impossibility of differentiating past from present infection with the Montenegro skin test 19,21,22, serological cross-reactivity with other parasites from the Tripanosomatidae family such as Trypanosoma cruzi 13,23, detection of antibodies against Leishmania in individuals who have had contact with the parasite but without developing the disease 20, and non-detection of antibody titers suggestive of infection, since the humoral response in tegumentary leishmaniasis is less intense than the cellular response 17 .

Parasite DNA detection methodologies have become a useful tool for leishmaniasis diagnosis, using specific extra-nuclear DNA sequences in the parasite's kinetoplast (k-DNA) 19,24,25. The DNA is divided into two distinct sequences, the maxi-circle and the mini-circle. In the mini-circle, base sequences are conserved among species of the Leishmania genus and also regions which vary among species 24 . Primers that amplify parasite DNA of the Leishmania genus have been used by various researchers and show high sensitivity and specificity 22,25,26,27,28.

To investigate Leishmania sp. infection in dogs from a rural area in northwestern Paraná State, Brazil, where there was an ATL outbreak in 2002, we performed polymerase chain reaction (PCR) and some commonly applied laboratory techniques such direct parasite search in lesions and indirect immunofluorescence (IIF).

\section{Materials and methods}

\section{Study area}

The county of Mariluz is located in the northwestern Paraná State, $594 \mathrm{~km}$ from the State capital Curitiba between $24^{\circ} 00^{\prime} \mathrm{S}$ and $53^{\circ} 10^{\prime} \mathrm{W}$, with an area of $391.53 \mathrm{~km}^{2}$ and $500 \mathrm{~m}$ altitude. It has a humid, subtropical, mesothermal climate with a mean temperature above $22^{\circ} \mathrm{C}$ in summer and below $18^{\circ} \mathrm{C}$ in winter.

\section{Dogs and biological samples}

In July 2003, 143 dogs from a rural area in Mariluz were studied. The animals were investigated for the presence of ATL suggestive lesions and enlarged lymph nodes.

Blood was drawn from all the animals. An aliquot of $2 \mathrm{ml}$ blood was added to an equal volume of ACD solution (25mM citric acid; $50 \mathrm{mM}$ sodium citrate; $81 \mathrm{mM}$ glucose). The material was frozen at $-20^{\circ} \mathrm{C}$ for later DNA extraction. The remaining blood was used for serum extraction and was stored at $-20^{\circ} \mathrm{C}$ until use.

Dogs with lesions were submitted to scraping and biopsies of the lesions' borders. Scrapings were taken with a DNA-free metallic scraper (previously treated with $1.5 \%$ hypochlorite solution for $15 \mathrm{~min}$ ). Smears were performed on glass slides for microscopic analysis for each type of biological sample taken from lesions. The remaining material collected from lesions (scrapings and biopsies) was placed in freezing vials with $100 \mu \mathrm{L}$ STE buffer (10mM TRIS; $1 \mathrm{mM}$ EDTA; 0.1M NaCl; $\mathrm{pH}$ 8.0) and stored in liquid nitrogen for later DNA extraction. Five animals presented palpable lymph nodes from which material was obtained by needle aspiration and submitted to the same treatment as that of lesions.

\section{Direct parasite search}

Slides containing material from lesions were Giemsa stained and analyzed for presence of amastigotes under 1,000x magnification.

\section{Indirect immunofluorescence (IIF)}

IIF was performed using as antigens promastigote forms of $L$. (V.) braziliensis, canine sera, and canine anti-immunoglobulin G conjugated with fluorescein (Sigma). Serum samples with titers equal to or greater than 40 were considered positive. Samples with significant Leishmania antibody titers were investigated for Trypanosoma cruzi antibodies by IIF, using Imunocruzi antigen (Biolab - Rio de Janeiro, Brazil).

\section{DNA extraction from lesional material and lymph node aspirates}

DNA extraction from lesional material and lymph node aspirates was performed using the Gentra Purogene ${ }^{\circledR}$ kit. After thawing the samples, $300 \mu$ of the lyse solution and $1.5 \mu$ l of $20 \mathrm{mg} / \mathrm{ml}$ Proteinase K were added. Samples were homogenized and incubated overnight, at $56^{\circ} \mathrm{C}$. After that, $1.5 \mu \mathrm{l}$ of $4 \mathrm{mg} / \mathrm{ml}$ RNAse were added and the samples were incubated for 1 hour, at $37^{\circ} \mathrm{C}$. Next, $100 \mu \mathrm{l}$ of the protein precipitation solution were added and the samples were shaken vigorously and centrifuged for 3 min., at 13,000g. The supernatant was transferred to another tube and the DNA was precipitated by the addition of $300 \mu$ of isopropanol. Samples were centrifuged at $13,000 \mathrm{~g}$, for $3 \mathrm{~min}$. 
The supernatant was discarded and $300 \mu$ of $70 \%$ ethanol were added to the sediment. Samples were centrifuged again at 13,000g, for 3 min. The supernatant was discarded, and the DNA was resuspended in $50 \mu$ of hydration solution. The final DNA was stored at $4^{\circ} \mathrm{C}$ until use.

\section{DNA extraction from blood samples}

The DNA was extracted from blood samples using the Phenol-Chloroform methodology described by Sambrook et al. 29 and modified as follows. Frozen blood was washed three times with $2 \mathrm{ml}$ of PBS $(0.01 \mathrm{M}$ phosphate buffer, $\mathrm{pH}$ $7.2 ; 0.15 \mathrm{M} \mathrm{NaCl}$ ) at $2,200 \mathrm{~g}$, for $10 \mathrm{~min}$. The cell sediment was broken and added of $200 \mu$ of the lyse solution (50mM Tris, pH $8.5 ; 50 \mathrm{mM}$ $\mathrm{NaCl} ; 25 \mathrm{mM} \mathrm{Na}{ }_{2}$ EDTA. $2 \mathrm{H}_{2} \mathrm{O}, \mathrm{pH} 8.0 ; 0.5 \%$ sodium dodecyl sulfate; $300 \mu \mathrm{g} / \mathrm{ml}$ proteinase $\mathrm{K})$. The resulting lysate was incubated for 4 hours, at $56^{\circ} \mathrm{C}$. After that, the lysate was added of $1.0 \mu \mathrm{l}$ of $4 \mathrm{mg} / \mathrm{ml}$ RNAse, and incubated at $37^{\circ} \mathrm{C}$, for 1 hour. Next, $200 \mu$ l of phenol-Tris (phenol equilibrated with Tris $0.1 \mathrm{M}, \mathrm{pH}$ 8.0) were added and the samples were incubated for 1 hour, at room temperature (approximately $25^{\circ} \mathrm{C}$ ), in a tube homogenizer. The sample was centrifuged at $3,000 \mathrm{~g}$, for $10 \mathrm{~min}$, and the upper phase was transferred to another tube and added of $200 \mu$ of phenol-Tris:chloroformisoamylic alcohol (49:1; vol:vol) at 1:1 (vol:vol). Samples were incubated for an hour, in a tube homogenizer, and centrifuged at $3,000 \mathrm{~g}$, for 10 $\min$. The supernatant was then transferred to another tube to which $200 \mu$ l of chloroform: isoamylic alcohol (49:1; vol:vol) were added. The material was incubated under agitation for 1 hour and then centrifuged at $3,000 \mathrm{~g}$, for $10 \mathrm{~min}$. The supernatant was then transferred to another tube and the DNA was precipitated by the addition of $25 \mu \mathrm{l}$ of $3 \mathrm{M}$ sodium acetate and $500 \mu \mathrm{l}$ of $100 \%$ ethanol. The tube was carefully inverted and subsequently centrifuged at $13,000 \mathrm{~g}$ for $3 \mathrm{~min}$. The sediment was washed once with $500 \mu \mathrm{l}$ of $70 \%$ ethanol followed by centrifugation $(13,000 \mathrm{~g}$, for $3 \mathrm{~min})$. The DNA pellet was resuspended in $50 \mu$ of TE buffer (TRIS 10mM; EDTA 1mM; pH 8.0) and stored at $4^{\circ} \mathrm{C}$ until use. As an extraction control, blood samples that were added of $L$. (V.) braziliensis promastigotes were extracted in the same way.

\section{DNA amplification}

The DNA amplification was carried out using the MP3H (GAA CGG GGT TTC TGT ATG C) and the MP1L (TAC TCC CCG ACA TGC CTC TG) primers described by Lopez et al. 25 , which amplify a fragment of 70 base pairs from the minicircles present in the kDNA of members of the $L$. braziliensis complex The PCR reaction mixture (25 $\mu \mathrm{l})$ contained $1 \mu \mathrm{M}$ of each MP1L and MP3H (Invitrogen ${ }^{\circledR}$ ), 0.2mM dNTP (Invitrogen ${ }^{\circledR}$ ), $1 \mathrm{U}$ Taq DNA Polymerase (Invitrogen ${ }^{\circledR}$ ), $2 \mu$ of the extracted DNA, $3 \mathrm{mM} \mathrm{MgCl}_{2}$, and $1 \mathrm{X}$ enzyme buffer. DNA amplification was carried out in a Biometra PC Thermocycler, using an initial heating of $95^{\circ} \mathrm{C}$, for $3 \mathrm{~min}$. Following the initial heating, 30 cycles were performed, each divided into three stages: denaturation $\left(95^{\circ} \mathrm{C}, 1.5 \mathrm{~min}\right)$, annealing $\left(56^{\circ} \mathrm{C}, 1.5 \mathrm{~min}\right)$, and elongation $\left(72^{\circ} \mathrm{C}\right.$, $2 \mathrm{~min})$. After the reaction, the material was kept at $72^{\circ} \mathrm{C}$ for $10 \mathrm{~min}$, and the amplified product was stored at $4^{\circ} \mathrm{C}$ until use. Amplified samples were submitted to electrophoresis in a $3 \%$ agarose gel stained with ethidium bromide. For each six samples analyzed in a gel, one positive and one negative control were added. After the run, the presence of amplified DNA bands was verified in a UV transilluminator (Macro Vue UV-20 Hoefer).

\section{Evaluation of PCR specificity and sensitivity}

The MP3H/MP1L primers specificity was evaluated in reactions using DNA from T. cruzi and from promastigotes of different Leishmania species that can cause ATL. L. (V.) braziliensis (MHOM/BR/1987/M11272) and L. (L.) amazonensis (MHOM/BR/1989/166MJO) were isolated from ATL patients at the Teaching and Research Laboratory for Clinical Analyses, State University of Maringá, Paraná, and identified at the Evandro Chagas Institute in Belém, Pará; L. (V.) panamensis (MHOM/PA/1967/BOYTON, L. (V.) guyanensis (MHOM/BR/1975/M4147), L. (V.) naiffi (MDAS/BR/1979/M5533), and L. (V.) lainsoni (MHOM/BR/1981/M6426) were kindly made available by Dr. J. J. Shaw, Evandro Chagas Institute/University of São Paulo, São Paulo. Promastigotes were cultured in 199 medium with $10 \%$ fetal bovine serum, $1 \%$ glutamine, and $1 \%$ human urine, at $25^{\circ} \mathrm{C}$, up to the stationary growth phase. Epimastigotes of $T$. cruzi strain Y grown in LIT medium were kindly made available by Dr. M. L. Gomes from the Basic Parasitology Laboratory, Department of Clinical Analyses, State University of Maringá.

The parasites were washed three times in PBS (720g for $15 \mathrm{~min}$.) and the sediment was resuspended in TE buffer, aliquoted, and stored at $-18^{\circ} \mathrm{C}$. DNA extraction was performed according to Belli et al. 19. Fifty-microliter aliquots of a parasite suspension in TE buffer were incubated with $100 \mu \mathrm{l}$ sterile water at $100^{\circ} \mathrm{C}$, for 
$10 \mathrm{~min}$. The sample was centrifuged at $13,000 \mathrm{~g}$, for $1 \mathrm{~min}$, and the supernatant was stored at $4^{\circ} \mathrm{C}$. Supernatant aliquots $(5 \mu \mathrm{l})$ were used for the PCR reaction. DNA concentration was estimated by absorbance at $260 \mathrm{~nm}$, according to Sambrook et al. 29. DNA was also extracted from lesional material obtained through scrapings and biopsies from 10 dogs presenting other types of skin diseases, which can be mistaken for tegumentary leishmaniasis, such as myiasis (1), demodectic scabies (3), mycosis (4), sarcoptic scabies (1), and seborrhea (1).

PCR technical sensitivity with the primers MP3H and MP1L was evaluated with DNA extracted from suspensions with different concentrations of $L$. (V.) braziliensis promastigotes.

\section{Statistical analysis}

Data were analyzed with the McNemar test using Statistica 6.0 software.

\section{Results}

Of the 143 investigated dogs, 87 (60.8\%) were male and 56 (39.2\%) female, with ages around two years. Thirty-nine $(27.3 \%)$ dogs presented lesions suggestive of ATL. Lesions were located in the ear in 23 dogs $(58.9 \%)$, muzzle in 6 (15.4\%), scrotum in $3(7.7 \%)$, ear and scrotum in $4(10.3 \%)$, muzzle and scrotum in $1(2.6 \%)$, ear, scrotum and muzzle in $1(2.6 \%)$, and ear, scrotum, muzzle, and paw in 1 (2.6\%).

PCR detected $0.9 \mathrm{fg}$ of DNA or 3.2 parasites/ $\mu$ of sample to be amplified. The MP3H/ MP1L primers amplified a fragment of DNA of $70 \mathrm{bp}$ of $L$. (V.) braziliensis, $L$. (V.) panamensis, $L$. (V.) guyanensis, L. (V.) naiffi, and $L$. (V.) lainsoni, belonging to the subgenus Viannia, but did not identify the $L$. (L.) amazonensis DNA. These primers did not amplify the DNA in lesional material from dogs with other skin diseases (myiasis, demodectic and sarcoptic scabies, mycosis, and seborrhea), thus showing $100 \%$ specificity. Figure 1 shows a PCR reaction performed with different $L$. (V.) braziliensis (A) concentrations and with lesional material (B).

Direct parasite search (scraping and/or biopsy) was positive in 5 (12.8\%) out of 39 dogs with lesions. Since some animals presented multiple lesions, 13 lesions were analyzed in these 5 dogs. Direct parasite search was positive in 4 out of $13(30.8 \%)$ scrapings and in 7 out of 9 $(77.8 \%)$ biopsies ( $p=0.1336)$. PCR was positive in 10 out of $13(76.9 \%)$ scrapings and in 8 out of $13(61.5 \%)$ biopsies $(p=0.4795)$. The five dogs with positive direct parasite search in at least one lesion also had positive PCR in at least one lesion. In three of these animals the PCR was performed in lymph nodes, one of which was positive.

Of the remaining 34 dogs with lesions and negative direct parasite search, 12 (35.3\%) had positive PCR. Eleven had positive PCR in lesional material, of which one was positive in both scraping and biopsy, five positive in scraping only, and five positive in biopsy only ( $\mathrm{p}=$ 0.7518). Two dogs were submitted to lymph node aspirate PCR, one of which was positive.

Table 1 shows the association between lesional PCR, direct parasite search, and IIF in 39 dogs with lesions. PCR detected 17 (43.6\%) and direct search 5 (12.8\%) positive dogs out of 39 dogs with lesions $(\mathrm{p}=0.0015)$. Lesional PCR was positive in: four dogs $(100 \%)$ with positive direct search and IIF; the one $(100 \%)$ with positive direct search and negative IIF; four $(57.1 \%)$ with negative direct search and positive IIF; and eight $(29.6 \%)$ with both negative direct search and negative IIF. All of the dogs had lower IIF titers for Chagas disease than for leishmaniasis. Positive lesional PCR was not statistically associated with positive IIF ( $p=0.1489$ ).

Blood PCR performed in 38 of 39 dogs with lesions was positive in 10 (26.3\%) (Table 2). Four $(4 / 11 ; 36.4 \%)$ had negative direct parasite search and positive lesional PCR. Another $27.3 \%(6 / 22)$ had both negative direct search and negative PCR. Only one was IIF-positive. No difference was found between parasite DNA detection in blood and either lesional direct search, lesional PCR ( $p=0.2386)$, or IIF ( $p=$ 1.000), showing that there was no correlation between DNA detection in blood and either DNA parasite detection in the lesion or antibody detection.

One hundred and four dogs did not have lesions suggestive of Leishmania sp. infection (Table 3). IIF was performed in 101 dogs and was positive in 17 (16.8\%). Of these, two (11.8\%) had positive blood PCR. Of the 84 dogs with negative IIF, 14 (16.7\%) had positive blood PCR. All animals with positive IIF were tested for Chagas disease, but the titers were lower than for leishmaniasis. Again, no relationship was found between parasite DNA detection in the blood and antibody detection $(p=1.0000)$ in dogs without lesions.

The association between blood and lesional PCR, direct parasite search, and IIF for ATL diagnosis showed $61.5 \%(24 / 39)$ positivity in symptomatic dogs and $29.8 \%(31 / 104)$ in asymptomatic. 


\section{Discussion}

This study investigated ATL in dogs from an endemic area where the causative agent for human infection is $L$. (V.) braziliensis 30 . PCR was applied and compared to both direct parasite search and IIF, aimed at overcoming some common limitations found in routine tests, such as low sensitivity in direct parasite search, especially in chronic infection 13,18,19,20. This limitation makes it impossible to differentiate past from present infection 19,21,22, serological crossreactivity 13,23, Leishmania antibody detection in individuals who have not developed the disease 20 , or lack of antibody titer detection suggestive of infection.

Of the 17 dogs with ATL lesions, four had multiple lesions and 13 had single lesions, predominantly in the ears, followed by the muzzle and scrotum. Prevalence of single lesions has also been mentioned by other authors 11,12, and predominance of lesions in the ears has also occurred in other ATL endemic areas 9,11,12.

PCR proved quite sensitive, capable of detecting 3.2 parasites/ $\mu \mathrm{l}$ or $0.9 \mathrm{fg}$ of DNA, similar to data described by Lopez et al. 25 , who detected $0.14 f \mathrm{~g}$ of DNA. The MP3H/MP1L primers amplified only DNA from species of Leishmania (Viannia) subgenus, including $L$. (V.) naiffi and $L$. (V.) lainsoni, not analyzed by Lopez et al. 25. PCR did not present false-negative results, not amplifying DNA extracted from material of lesions involving other etiologies.

Lesional PCR did not show false-negative results, detecting all cases in which the direct parasite search was positive. PCR sensitivity in detecting the disease was higher than that of direct search. While direct search detected $12.8 \%$ of affected dogs with lesions, PCR detected $43.6 \%(\mathrm{p}=0.0015)$. Concordance between direct search and lesional PCR was $69.2 \%$.

Comparison of the two methods for collecting material from lesions (biopsy or scraping) in the five dogs with positive direct search did not show any difference in positivity, either in direct search or PCR. However, of the 11 dogs with negative direct search and positive lesional PCR, ten had positive PCR in the material obtained by only one of the methods, showing that the association ( $p=0.7518)$ between the two methods for collecting the material from lesions increases the likelihood of detecting infection, probably due to the scarce parasites in lesions 8 .

PCR results from lymph node aspirate were not associated with either direct search or lesional PCR, and only contributed to the diagnosis in one of five dogs studied, which had
Figure 1

Representative gel showing 70 base pair (bp) fragment of the k-DNA mini-circle region of Leishmania braziliensis complex, amplified by polymerase chain reaction using MP1L/MP3H primers.
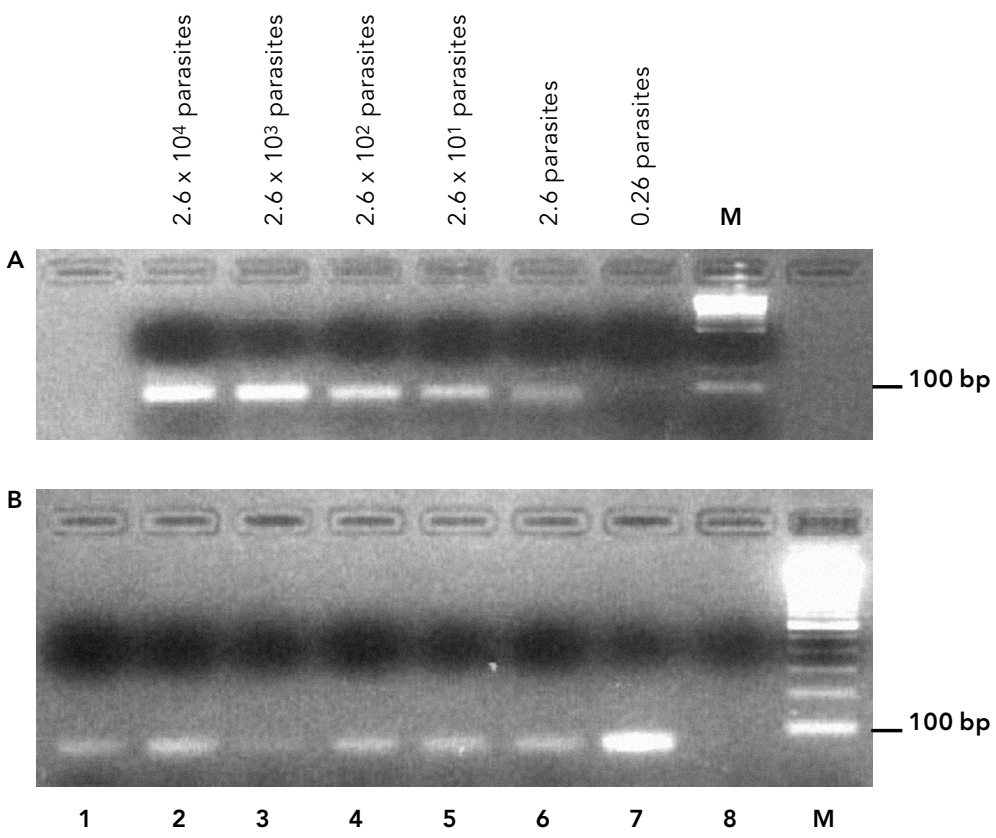

$\mathrm{A}=$ different concentrations of Leishmania (Viannia) braziliensis DNA were used DNA amplified corresponding to $2.6 \times 103$ to 0.26 parasites; $B=$ lane 1 to 6 , positive lesions from dogs; lane 7 , positive control [DNA extracted from Leishmania (Viannia) braziliensis promastigotes]; lane 8 , negative control (mixed reaction); $\mathrm{M}=$ molecular weight standards.

Table 1

Results of polymerase chain reaction (PCR) (lesion and/or lymph nodes) compared to direct parasite search (DP) and indirect immunofluorescence (IIF) in dogs with lesions suggestive of American tegumentary leishmaniasis.

\begin{tabular}{lccc}
\hline DP/IIF & Dogs with & \multicolumn{2}{c}{ PCR } \\
& lesions (n) & Positive (n) & Positivity (\%) \\
\hline Positive/Positive & 4 & 4 & 100.0 \\
Positive/Negative & 1 & 1 & 100.0 \\
Negative/Positive & 7 & 4 & 57.1 \\
Negative/Negative & 27 & 8 & 29.6 \\
Total & 39 & 17 & 43.7 \\
\hline
\end{tabular}

$p=0.0015$, McNemar test, $P C R$ versus DP.

$\mathrm{p}=0.1489$, McNemar test, PCR versus IIF. 
Table 2

Results of polymerase chain reaction (PCR) in blood compared to direct parasite search (DP), PCR in lesion, and indirect immunofluorescence (IIF) in dogs with lesions suggestive of American tegumentary leishmaniasis.

\begin{tabular}{lccc}
\hline DP/PCR (lesion)/IIF & $\begin{array}{c}\text { Dogs with } \\
\text { lesions (n) }\end{array}$ & $\begin{array}{c}\text { PCR (blood) } \\
\text { Positive (P/N) }\end{array}$ & $\begin{array}{l}\text { Positivity (\%) } \\
\text { Positive/Positive/Positive }\end{array}$ \\
Positive/Positive/Negative & 4 & $0 / 4$ & 0.0 \\
Negative/Positive/Positive & 4 & $0 / 1$ & 0.0 \\
Negative/Positive/Negative & 8 & $1 / 3$ & 33.3 \\
Negative/Negative/Positive & 2 & $3 / 8$ & 37.5 \\
Negative/Negative/Negative & 20 & $1 / 2$ & 50.0 \\
Total & 39 & $5 / 20$ & 25.0 \\
\hline
\end{tabular}

$\mathrm{P}=$ number positive; $\mathrm{N}=$ number analyzed;

$P=0.2386, \mathrm{McNemar}$ test, $\mathrm{PCR}$ in blood versus DP and/or PCR in lesion;

$\mathrm{p}=1.0000, \mathrm{McNemar}$ test, $\mathrm{PCR}$ in blood versus IIF.
Table 3

Results of polymerase chain reaction (PCR) in blood compared to indirect immunofluorescence (IIF) in dogs without lesions suggestive of American tegumentary leishmaniasis.

\begin{tabular}{lccc}
\hline IIF & $\begin{array}{c}\text { Dogs without } \\
\text { lesions (n) }\end{array}$ & \multicolumn{2}{c}{ PCR (blood) } \\
Positive (P/N) & Positivity (\%) \\
\hline Positive & 17 & $2 / 17$ & 11.8 \\
Negative & 84 & $14 / 84$ & 16.7 \\
Not done & 3 & $0 / 3$ & 0.0 \\
Total & 104 & $16 / 104$ & 15.4 \\
\hline
\end{tabular}

$\mathrm{P}=$ number positive; $\mathrm{N}=$ number analyzed;

$p=1.0000$, McNemar test.
Leishmania DNA detection in the blood of dogs in endemic areas has been reported by other authors 15,32,33. In the current study, detection of parasite DNA in the blood of $26.3 \%$ of dogs with lesions and $15.4 \%$ of those without lesions shows that presence of parasite DNA in blood does not correlate to presence of lesions ( $\mathrm{p}=0.0973)$. Reithinger et al. 15 found Leishmania (Viannia) DNA in the blood of only $7.11 \%$ of asymptomatic dogs in endemic areas of $L .(V)$. braziliensis and $L .(V$.$) peruviana$ in Peru, although $18.18 \%$ of symptomatic dogs had positive PCR in blood. Still, according to these authors, Leishmania DNA was detected in the blood of a large number of dogs that were investigated, suggesting that hematogenous dissemination is more common than previously thought. Blood samples from the majority of dogs with active lesions (positive biopsy smear) were negative in blood PCR 15. This report agrees with our findings, since Leishmania DNA was not detected in the blood of any of the dogs with positive direct search, although $36.4 \%$ of the dogs with positive lesional PCR had positive blood PCR. A possible explanation is that Leishmania (Viannia) parasites locate first in the cutaneous infection site, and as the infection progresses they disappear from the lesion and spread via the bloodstream. If this explanation is true, dogs could be acting as a secondary ATL reservoir. However, the data accumulated thus far do not allow drawing this conclusion.

Parasite DNA detection in the blood of dogs with negative serology has also been reported previously. Reithinger et al. 32 also found dogs with positive PCR in the blood and negative ELISA and explained the finding by the fact that the dogs had still not developed their immune response to the infection (pre-patent period). Follow-up of these animals showed that $21 \%$ eventually became ELISA-positive.

Altogether, use of lesional or blood PCR, direct parasite search, and IIF detected $61.5 \%$ of positive dogs among the symptomatic animals and $29.8 \%$ among asymptomatic, thus increasing the efficiency of ATL diagnosis in dogs. These tests also showed a high ATL endemicity in the study area. The data show that the use of PCR for detecting Leishmania DNA in canine blood, associated with other diagnostic tests, may help determine the extent of ATL sub-clinical infections, in agreement with Reithinger \& Davies 34 .

The results also show that although lesional PCR can be more expensive when compared to direct parasite search, it may be useful for ATL diagnosis in dogs due to its higher positivity 
(3.4 times). Material obtained from lesions by more than one method increases the likelihood of detecting infection in canine lesions, probably because of the scarcity of parasites in lesions. No relationship was observed between serology, presence of active lesions, and detection of parasite DNA in blood. ATL prevalence was high in both symptomatic and asymptomatic animals assessed by direct parasite search, IIF, and PCR. Moreover, these results corrobo- rate previous reports that the parasite's hematogenous dissemination in dogs is not a rare occurrence, reinforcing the hypothesis that dogs may act as a possible secondary ATL reservoir in some areas of $L$. (V.) braziliensis transmission in Brazil. Follow-up studies in dogs in endemic areas are being conducted and may shed new light on the role of canines in the ATL transmission cycle.

\section{Resumo}

A leishmaniose tegumentar americana (LTA) foi estudada em 143 cães da área rural no Município de Mariluz, noroeste do Estado do Paraná, Brasil, utilizando a pesquisa direta do parasito (PD), a imunofluorescência indireta (IFI) e a reação em cadeia da polimerase (PCR). Trinta e nove cães (27,3\%) apresentavam lesões sugestivas da doença, 5 (12,8\%) deles foram positivos na PD e PCR em tecido de lesão, e quatro foram também positivos na IFI. Dos 34 cães com PD negativa, 12 (35,3\%) tiveram a PCR (lesão) positiva, e cinco desses tiveram também IFI positiva. Cento e quatro cães não apresentavam lesão, mas 17/101 (16,8\%) tiveram IFI positiva. A PCR no sangue foi positiva em 10/38 (26,3\%) cães com lesão e em 16/104 (15,4\%) sem lesão. A associação entre PCR (lesão ou sangue), PD e IFI detectou 24/39 (61,5\%) positivos entre os cães sintomáticos e $31 / 104$ (29,8\%) positivos entre os assintomáticos. A PCR foi útil para o diagnóstico de LTA, não houve relação entre presença de lesão, sorologia e PCR no sangue, e a detecção de DNA do parasito no sangue pode indicar a ocorrência de disseminação hematogênica do parasito.

Leishmaniose; Leishmania (Viannia) braziliensis; Reação em Cadeia da Polimerase; Técnica Indireta de Fluorescência para Anticorpo; Cães

\section{Contributors}

L. G. Velasquez participated in the field collection of biological material, laboratory tests, and elaboration of the manuscript. N. Membrive, U. Membrive, G. Rodrigues, and N. Reis contributed to the field collection of biological material. M. V. C. Lonardoni and U. Teodoro contributed to the data analysis, elaboration of the manuscript, and final revision of the text. I. P. B. Tessmann contributed to the standardization of assays and elaboration of the manuscript. T. G. V. Silveira oriented the research work, contributed to the data analysis, elaboration of the manuscript, and final revision of the text.

\section{Acknowledgements}

This work was supported by the Brazilian National Research Council (CNPq) and the Araucária Foundation.

\section{References}

1. Rey L. Parasitologia. Rio de Janeiro: Editora Guanabara Koogan; 2001.

2. Hepburn NC. Cutaneous leishmaniasis an overview. J Postgrad Med 2003; 49:50-4.

3. Silveira TGV, Teodoro U, Lonardoni MVC, Toledo MJO, Bertolini, DA, Arraes SMAA, et al. Investigação sorológica em cães de área endêmica de leishmaniose tegumentar no Estado do Paraná, Sul do Brasil. Cad Saúde Pública 1996; 12:89-93.

4. Lima AP, Minelli L, Teodoro U, Comunello E. Distribuição da leishmaniose tegumentar por imagens de sensoriamento remoto orbital, nos Estado do Paraná, Brasil. An Bras Dermatol 2002; 77:681-92.

5. Teodoro U, Silveira TGV, Santos DR, Santos ES, Santos AR, Oliveira O, et al. Freqüência da fauna de flebotomíneos no domicílio e em abrigos de animais domésticos no peridomicílio, nos municípios de Cianorte e Doutor Camargo - Estado do Paraná, Brasil. Rev Patol Trop 2001; 30:209-23.

6. Castro EA, Soccol VT, Membrive N, Luz E. Estudo das características epidemiológicas e clínicas de 332 casos de leishmaniose tegumentar notificados na região norte do estado do Paraná de 1993 a 1998. Rev Soc Bras Med Trop 2002; 35:445-52.

7. Serra CMB, Leal CA, Figueiredo F, Schulbach TM, Duarte R, Uchôa CMA, et al. Leishmaniose tegumentar canina em Morada das Águias (Serra da Tiririca), Maricá, Rio de Janeiro, Brasil. Cad Saúde Pública 2003; 19:1877-80.

8. Marco JD, Padilla AM, Diosque P, Fernández MM, Malchiodi EL, Basombrío MA. Force of infection and evolution of lesions of canine tegumentary leishmaniasis in Northwestern Argentina. Mem Inst Oswaldo Cruz 2001; 96:649-52.

9. Madeira MF, Uchôa CMA, Leal CA, Silva RD, Magalhães CM, Serra CMB. Leishmania (Viannia) 
braziliensis em cães naturalmente infectados. Rev Soc Bras Med Trop 2003; 36:551-5.

10. Lonardoni MVC, Teodoro U, Arraes SMAA, Silveira TGV, Bertolini DA, Ishikawa EAY, et al. Nota sobre leishmaniose canina no noroeste do Estado do Paraná, sul do Brasil. Rev Saúde Pública 1993; 27:378-9.

11. Falqueto A, Coura JR, Barros GC, Grimaldi FG, Sessa PA, Carias VRD, et al. Participação do cão no ciclo de transmissão da leishmaniose tegumentar no município Viana, Estado do Espírito Santo, Brasil. Mem Inst Oswaldo Cruz 1986; 81: 155-63.

12. Pirmez C, Coutinho SG, Marzochi MCA, Nunes PM, Grimaldi Jr. G. Canine American cutaneous leishmaniasis: a clinical and immunological study in dogs naturally infected with Leishmania (Viannia) braziliensis in an endemic area of Rio de Janeiro, Brazil. Am J Trop Med Hyg 1988; 38:52-8.

13. Reithinger R, Davies CR. Is the domestic dog ( $\mathrm{Ca}$ nis familiaris) a reservoir of American cutaneous leishmaniasis? A critical review of the current evidence. Am J Trop Med Hyg 1999; 61:530-41.

14. Reithinger R, Lambson BE, Barker DC, Counihan H, Espinoza JC, González JS, et al. Leishmania (Viannia) ssp. dissemination and tissue tropism in naturally infected dogs (Canis familiaris). Trans R Soc Trop Med Hyg 2002; 96:76-8.

15. Reithinger R, Lambson BE, Barker DC, Davies CR. Use of PCR to detect Leishmania (Viannia) sp. in dog blood and bone marrow. J Clin Microbiol 2000; 38:748-51.

16. Ramírez JR, Agudelo S, Muskus C, Alzate JF, Berberich C, Barker D, et al. Diagnosis of cutaneous leishmaniasis in Colombia: the sampling site within lesions influences the sensitivity of parasitologic diagnosis. J Clin Microbiol 2000; 38:3768-73.

17. Badaró R, Reed SG. Leishmanioses. In: Ferreira EW, Ávila SLM, organizadores. Diagnóstico laboratorial das principais doenças infecciosas e auto-imunes. Rio de Janeiro: Editora Guanabara Koogan; 2001. p. 255-62.

18. Singh S, Sivakumar R. Recent advantages in the diagnosis of leishmaniasis. J Postgrad Med 2003; 49:55-60.

19. Belli A, Rodrigues B, Aviles H, Harris E. Simplified polymerase chain reaction detection of New World Leishmania in clinical specimens of cutaneous leishmaniasis. Am J Trop Med Hyg 1998; 58:102-9.

20. Piñero J, Martínez E, Pacheco R, Aragón Z, De Armas F, Del Castilho A, et al. PCR-ELISA for diagnosis of mucocutaneous leishmaniasis. Acta Trop 1999; 73:21-9.

21. Weigle KA, Labrada LA, Lozano C, Santrich C, Barker DC. PCR-based diagnosis of acute and chronic cutaneous leishmaniasis caused by Leishmania (Viannia). J Clin Microbiol 2002; 40:601-6.

22. Hu X, Tang W, Lu H, Yan H, Cheng J, Ma Y, et al. Sequencing a specific kinetoplast DNA fragment of Leishmania donovani for polymerase chain reaction amplification in diagnosis of leishmaniasis in bone marrow and blood samples. J Parasitol 2000; 86:822-6.
23. Vexenat AC, Santana JM, Teixeira AR. Cross-reactivity of antibodies in human infections by kinetplastid protozoa Trypanosoma cruzi, Leishmania chagasi and Leishmania (Viannia) braziliensis. Rev Inst Med Trop São Paulo 1996; 38:177-85.

24. Rodgers MR, Popper SJ, Wirth DF. Amplification of kinetoplast DNA as a tool in the detection and diagnosis of Leishmania. Exp Parasitol 1990; 71: 267-75.

25. Lopez $M$, Inga $R$, Cangalaya $M$, Echevarria J Cuentas AL, Orrego C, et al. Diagnosis of Leishmania using the polymerase chain reaction: a simplified procedure for field work. Am J Trop Med Hyg 1993; 49:348-56.

26. Noyes HA, Reyburn H, Bailey W, Smith D. A nested-PCR-based schizodeme method for identifying Leishmania kinetoplast minicircle classes directly from clinical samples and its application to the study of the epidemiology of Leishmania tropica in Pakistan. J Clin Microbiol 1998; 36:2877-81.

27. Harris E, Krop G, Belli A, Rodrigues B, Agabian N. Single-step multiplex PCR assay for characterization of New World Leishmania complex. J Clin Microbiol 1998; 36:1989-95.

28. Brenière SF, Teleria J, Bosseno MF, Buitra GOR, Bastrenta B, Cuny G, et al. Polymerase chain reaction-based identification of New World Leishmania species complex by specific kDNA probes. Acta Trop 1999; 73:283-93.

29. Sambrook J, Fritsch EF, Maniatis T. Molecular cloning: a laboratory manual. New York: Cold Spring Harbor Laboratory Press; 1989.

30. Alves W, Maia NA, Ramalho W, Urdeneta M, Hatch D, Romero G, et al. Outbreak of cutaneous leishmaniasis in Paraná State, Brazil. In: XIX Reunião Anual de Pesquisa em Doença de Chagas e VII Reunião Anual de Pesquisa Aplicada em Leishmaniose. Uberaba: Sociedade Brasileira de Medicina Tropical; 2003. p. 75.

31. Uchôa CMA, Serra CMB, Duarte R, Magalhães CM, Macedo RM, Theophilo F, et al. Aspectos sorológicos e epidemiológicos da leishmaniose tegumentar americana canina em Marica, Rio de Janeiro, Brasil. Rev Soc Bras Med Trop 2001; 34: 563-8.

32. Reithinger R, Espinoza JC, Coutenay O, Davies CR. Evaluation of PCR as diagnostic mass-screening tool to detect Leishmania (Viannia) spp. in domestic dogs (Canis familiaris). J Clin Microbiol 2003; 41:1486-93.

33. Llanos-Cuentas EA, Roncal N, Villaseca P, Paz L, Ogusuku E, Perez JE, et al. Natural infections of Leishmania peruviana in animals in the Peruvian Andes. Trans R Soc Trop Med Hyg 1999; 93:15-20.

34. Reithinger R, Davies R. American cutaneous leishmaniasis in domestic dogs: an example of the use of the polymerase chain reaction for mass screening in epidemiological studies. Trans R Soc Trop Med Hyg 2002; 96 Suppl 1:S123-6.

Submitted on $11 /$ Jan/2005

Final version resubmitted on $03 /$ Jun/2005 Approved on 10/Jun/2005 